\title{
Properties of phenoloxidase from haemocytes of Scylla tranquebarica
}

\author{
A. S. Sabu*, K. P. Jithendran, C Gopal \\ Central Institute of Brackishwater Aquaculture 75, Santhome High Road, R. A. Puram, Chennai - 600 028, India.
}

\author{
ARTICLE INFO \\ Article history: \\ Received on: 10/11/2015 \\ Revised on: 14/12/2015 \\ Accepted on: 07/01/2016 \\ Available online: 19/02/2016 \\ Key words: \\ Crab, Scylla tranquebarica, \\ Haemocyte, \\ Prophenoloxidase,
}

Phenoloxidase.

\begin{abstract}
The presence of phenoloxidase (PO) activity in the haemocytes of Scylla tranquebarica was electrophoretically and spectrophotometrically studied. Majority of the enzyme was located as proenzyme, prophenoloxidase (proPO) in the haemocytes. The enzyme prefers L-dihydroxyphenylalanine (L-dopa) as its substrate than phenol and is optimally active at pH 8.0. Besides trypsin, the proPO was also activated by both Gram positive and Gram negative microbes in vitro while, chemicals such as sodium azide, thiourea and EDTA significantly inhibited the enzyme expression. The protein needs considerable levels of divalent cations like calcium $\left(20 \mathrm{mM}\right.$ as $\left.\mathrm{CaCl}_{2}\right)$ or magnesium (20-50 $\mathrm{mM}$ as $\mathrm{MgCl}_{2}$ ) for its activity. The gel filtration chromatography of haemocyte lysate supernatant showed a single major peak of protein having PO activity. Electrophoresis of purified PO by native PAGE revealed a single prominent band of approximately $167.2 \mathrm{kDa}$ which was further resolved to three bands having molecular mass of approximately 77.1, 56.9 and 30.2 kDa respectively, on SDS-PAGE.
\end{abstract}

\section{INTRODUCTION}

Decapods utilise two broad categories of defence responses against invading pathogens namely, cellular and humoral. Cellular immune response functions for encapsulation, phagocytosis and nodule formation [1] while the antibacterial proteins, clotting system and prophenoloxidase (proPO) system belongs to humoral immune responses [2, 3]. The prophenoloxidase system is considered as an important mechanism of innate defence in arthropods. Its active form phenoloxidase (PO), a copper containing enzyme, catalyzes two successive reactions; hydroxylation of a monophenol to odiphenol and oxidation of o-diphenol to o-quinone and initiate the synthesis of melanin that will act as a toxin against microorganisms [4]. The location of proPO is highly varied among arthropods. However, in decapod crustaceans, proPO is located mainly in granular haemocytes and haemocyte lysate supernatant was used as the enzyme source [5-8]. Although, the presence of a proPO system involved in non-self recognition is well documented in decapods, no such reports are available for Scylla tranquebarica. Therefore the objective of this paper was

\footnotetext{
* Corresponding Author

Dr. A. S. Sabu, Kostae Aqua Biotech, First Floor, Thalipparambil, Nalanchira P.O., Trivandrum, Kerala, India. Phone: 91-9526501843 Email:drsabuas@gmail.com
}

to study the main biochemical properties of proPO from haemocytes of $S$. tranquebarica.

\section{MATERIALS AND METHODS}

\subsection{Animals}

Crabs, Scylla tranquebarica $(7.5 \pm 0.5 \mathrm{~cm} ; 60 \pm 1.9 \mathrm{~g})$ were collected from Muttukkadu creek, Chennai, India. Twenty crabs were maintained in two-ton fibreglass tanks containing seawater (pH: $8.3 \pm 0.2$; salinity: $26 \pm 1.0 \mathrm{ppt}$; temperature: $25 \pm 1.0{ }^{\circ} \mathrm{C}$ ) for an acclimatization period of 20 days. The water was aerated continuously and changed once a day. The animals were fed with boiled clam meat during the period of study. Only healthy crabs, with no missing limbs and carapace lesions were used for the experiment.

\subsection{Haemocyte lysate preparation}

The animals were bled, after surface sterilization with $70 \%$ ethanol, directly from the sinuses of the appendages using 26 guage needle fitted to sterile $2 \mathrm{ml}$ plastic syringe containing anticoagulant solution $(0.14 \mathrm{M} \mathrm{NaCl}, 0.1 \mathrm{M}$ glucose, $30 \mathrm{mM}$ trisodium citrate, 10 mM EDTA, $\mathrm{pH}$ 7.2) at 1:1 ratio.

The hemolymph was transferred to $1.5 \mathrm{ml}$ eppendorff tubes and held on ice cubes, then centrifuged at $700 \mathrm{~g}$ for $10 \mathrm{~min}$ at $4{ }^{\circ} \mathrm{C}$ and pellet was separated. The supernatant, plasma collected separately also used for detecting the PO activity. 
The cell pellets were resuspended in sodium cacodylate buffer, CAC1 (10 mM sodium cacodylate, $0.45 \mathrm{M} \mathrm{NaCl}, 20 \mathrm{mM}$ $\mathrm{CaCl}_{2}, 30 \mathrm{mM} \mathrm{MgCl}, \mathrm{pH}$ 8.0) and homogenised. The resultant solution was centrifuged at $16,000 \mathrm{~g}$ for $45 \mathrm{~min}$ at $4{ }^{\circ} \mathrm{C}$. The supernatant designated as haemocyte lysate supernatant (HLS) was stored in aliquots at $4{ }^{\circ} \mathrm{C},-4{ }^{\circ} \mathrm{C}$ and $-30{ }^{\circ} \mathrm{C}$ separately and used as enzyme source for further study.

\subsection{Determination of phenoloxidase activity}

PO activity was measured by recording the formation of dopachrome from L-dopa from HLS and plasma [9]. Briefly, $50 \mu 1$ of HLS was incubated with same quantity of trypsin $\left(2 \mathrm{mg} \mathrm{ml}^{-1}\right.$ of CAC1 buffer) in 96 well flat bottom microtitre plate (Tarsons) for $20 \mathrm{~min}$ at $25{ }^{\circ} \mathrm{C}$. Then, $100 \mu \mathrm{l}$ of L-dopa ( $3 \mathrm{mg} \mathrm{ml}-1$ in CAC1 buffer) was added. Absorbance was measured after 5 min at 490 $\mathrm{nm}$ using a MULTISCAN ELISA Reader (Labsystems, Finland) for $20 \mathrm{~min}$ at every $2 \mathrm{~min}$ intervals. PO activity is expressed as units; one unit of enzyme was defined as the increase in absorbance of $0.001 \mathrm{~min}^{-1} \mathrm{mg}^{-1}$ of protein. The concentration and quantity of trypsin and L-dopa used for the assay of PO throughout the present study was same unless specified.

\subsection{Substrate specificity and $K_{\mathrm{m}}$ determination for $P O$ activity}

Substrate specificity and $K_{\mathrm{m}}$ determination was employed for L-dopa and phenol. For this, $50 \mu \mathrm{l}$ of HLS was first incubated with trypsin for $20 \mathrm{~min}$ at $25{ }^{\circ} \mathrm{C}$ and then PO activity was measured by adding $100 \mu \mathrm{l}$ of substrates at various concentrations $(0.5,1,2,5,10,15,20,25$ and $30 \mathrm{mM})$ into it. The reaction velocity was calculated from Lineweaver-Burk plots. The kinetic method at maximum absorbance $\left(V_{\max }\right)$ was used to determine the velocity of the reaction. The $K_{\mathrm{m}}$ for L-dopa and phenol was calculated from the result of the experiment.

\subsection{Effect of $\mathrm{pH}$ on $\mathrm{PO}$ activity}

To determine the optimum $\mathrm{pH}$ required for $\mathrm{PO}$ activity, $50 \mu \mathrm{l}$ of HLS was incubated with trypsin and $100 \mu \mathrm{l}$ of L-dopa (3 $\mathrm{mg} \mathrm{ml}^{-1}$ ), dissolved in phosphate buffer having different $\mathrm{pH}$ (3.0 to 8.5 with 0.5 increment) was added and absorbance was measured at $490 \mathrm{~nm}$. The $\mathrm{pH}$ having the highest activity was considered as optimum $\mathrm{pH}$ for $\mathrm{PO}$ from haemocytes of S. tranquebarica.

\subsection{Effect of exogenous elicitors on $P O$ activity}

The elicitors used in the present study were: (a) buffer control (CAC1) (b) trypsin (c) different Gram-negative bacteria of Vibrio spp viz., Vibrio cholerae, V. parahaemolyticus, V. mimicus, $V$. fluvialis, V. harveyi, V. mediterreni, V. logei, V. campbellii, V. alginolyticus, V. fisherii, V. vulnificus and (d) a Gram-positive bacteria, Streptococcus fecalis. All microbes were isolated and identified [10] from shrimp, Penaeus monodon, collected from culture ponds in Mahabalipuram, Tamil Nadu (India). All bacteria were grown in Brain Heart Infusion broth with $1.5 \% \mathrm{NaCl}$ at 37 ${ }^{\circ} \mathrm{C}$ and cells were harvested by centrifugation at $5000 \mathrm{~g}$ for $20 \mathrm{~min}$ at $4{ }^{\circ} \mathrm{C}$. The bacterial pellet was washed and centrifuged twice with sterile PBS. The final pellet was resuspended in sterile PBS and made the final concentration of $10^{7}$ cells $\mathrm{ml}^{-1}$. For detecting the enzyme activity, $50 \mu 1$ of HLS was incubated with $50 \mu 1$ of different elicitors for $20 \mathrm{~min}$ at $25{ }^{\circ} \mathrm{C}$. The PO was then detected using L-dopa as above.

\subsection{Effect of inhibitors on $P O$ activity}

The compounds tested for inhibition assay were: thiourea, sodium azide and EDTA. To $50 \mu \mathrm{l}$ of HLS, an equal quantity of trypsin was added and incubated for $20 \mathrm{~min}$. Subsequently, $50 \mu \mathrm{l}$ of $10 \mathrm{mM}$ inhibitor solutions were added and incubated for $30 \mathrm{~min}$ at $25{ }^{\circ} \mathrm{C}$. Finally, $100 \mu \mathrm{l}$ of L-dopa was added and PO activity was measured. A control set with $50 \mu 1$ of CAC1 buffer was also used instead of the inhibitor solution for phenoloxidase activity. Percentage reduction of PO activity was calculated between the trypsin treated and samples having inhibitors.

\subsection{Calcium and magnesium dependence on PO activity}

In order to study the calcium and magnesium dependence on PO activity, HLS was prepared with CAC2 buffer (10mM sodium cacodylate). Fifty $\mu \mathrm{l}$ of the prepared HLS were incubated with trypsin for $20 \mathrm{~min}$ and divided into two groups. To the first group, $50 \mu \mathrm{l}$ of $5,10,20,50$ and $100 \mathrm{mM} \mathrm{CaCl}_{2}$ was added while in the other group, same quantity of $\mathrm{MgCl}_{2}$ was added and incubated for $20 \mathrm{~min}$. PO activity was measured after adding Ldopa. The concentration of divalent cation that shows the highest PO activity was selected as optimum level required for the assay.

\subsection{Storage stability}

To study the storage stability at different temperatures, the prepared HLS was kept at $4,-4$ and $-30{ }^{\circ} \mathrm{C}$. PO was determined after 7, 14, 21, 28 and 35 days. The percentage reduction of PO was calculated by comparing its activity with that of initial day (73.14 \pm 2.25 units).

\subsection{Enzyme purification by gel filtration chromatography}

Three $\mathrm{ml}$ of HLS containing $140 \mathrm{mg} \mathrm{ml}^{-1}$ of protein was applied to a Sephadex G 200 (Pharmacia, Sweden) column (30 X 2 $\mathrm{cm}$ ) equilibrated with CAC1 buffer. The column was eluted with the same buffer at a flow rate of $1 \mathrm{ml} \mathrm{min}{ }^{-1}$, the first $30 \mathrm{ml}$ was discarded and then $3 \mathrm{ml}$ fractions were collected. Protein concentrations and PO was determined for each fraction. The fractions showing high proPO activity were pooled and concentrated by dialysis bag (Hi-Media) with $10 \mathrm{kDa}$ molecular cut off against sucrose followed by equilibration with distilled water. The samples were then stored at $-30{ }^{\circ} \mathrm{C}$ until further study.

\subsection{Polyacrylamide gel electrophoresis (PAGE) of partially purified proPO}

Polyacrylamide gel electrophoresis of the partially purified proPO was performed using $10 \%$ gels and Tris-glycine buffer ( $\mathrm{pH} 8.3$ ), run under native and denaturing conditions [11]. For native PAGE, the gel was run at $130 \mathrm{~V}$ for $4 \mathrm{~h}$ and molecular weight markers from 44 to $205 \mathrm{kDa}$ were included. SDS-PAGE 
was run at $80 \mathrm{~V}$ for $3 \mathrm{~h}$, using protein from 14 to $97.4 \mathrm{kDa}$ as molecular weight markers. To observe proPO band, the gels were incubated with trypsin $\left(2 \mathrm{mg} \mathrm{ml}^{-1}\right.$ of $\mathrm{CAC} 1$ buffer) solution at 25 ${ }^{\circ} \mathrm{C}$ for $30 \mathrm{~min}$, washed thrice with distilled water and then incubated with L-dopa ( $3 \mathrm{mg} \mathrm{ml}^{-1}$ of CAC1 buffer) for $45 \mathrm{~min}$. Gels were then washed three times with distilled water and stained with $0.1 \%$ coomassie brilliant blue for detecting the protein bands.

\subsection{Protein estimation}

Protein concentration in HLS and fractions of column during gel filtration was estimated by the method of Lowry et al [12] using bovine serum albumin as standard.

\subsection{Statistical analysis}

Significance was determined with Student's $t$-test and differences between results were considered significant at $P<0.05$.

\section{RESULTS}

The main biochemical and molecular properties of prophenoloxidase in haemocytes of $S$. tranquebarica are given below.

\subsection{Presence of phenoloxidase activity}

The spectrometric analysis in the present study revealed the oxidation of L-dopa by PO in HLS of crab, S. tranquebarica (Table 1). The activity of PO was found to be higher in HLS than in plasma and it needs a serine protease like trypsin to convert proPO to active PO. Thus, the result confirms the distribution of proPO in this crab is confined to haemocytes and haemocyte lysate can be used for determining its activity.

Table 1: PO activity from haemocyte lysate supernatant (HLS) and plasma of Scylla tranquebarica $($ mean $\pm \mathrm{SD} ; \mathrm{n}=8)$.

\begin{tabular}{lc}
\hline Sample & PO activity (units $\mathbf{~ m i n}^{-1} \mathbf{~ m}^{-1}$ of protein) \\
\hline HLS & $134.18 \pm 3.48$ \\
Plasma & $2.42 \pm 0.45$ \\
\hline
\end{tabular}

\subsection{Substrate specificity, $\mathrm{Km}$ and $\mathrm{pH}$ determination for $\mathrm{PO}$ activity}

To determine the PO specificity, various concentrations (0.5-30 mM) of L-dopa and phenol were used as substrates. Interestingly the results showed higher specificity for L-dopa than phenol. Table 2 shows the $K_{\mathrm{m}}(\mathrm{mM})$ and $V_{\max }\left(\Delta \mathrm{Abs} \min ^{-1}\right)$ based on Lineweaver-Burk model for the above substrates.

Table 2: $K_{\mathrm{m}}$ and maximum velocity of crab proPO with L-dopa and phenol as substrates.

\begin{tabular}{lcc}
\hline Substrate(s) & $\boldsymbol{K}_{\mathbf{m}}(\mathbf{m M})$ & $\boldsymbol{V}_{\max }\left(\boldsymbol{\Delta} \mathbf{A b s} \mathbf{~ m i n}^{-1}\right)$ \\
\hline L-dopa & 2.10 & 2.458 \\
Phenol & 4.03 & 0.003 \\
\hline
\end{tabular}

Meanwhile, the enzyme was found to be inactive at $\mathrm{pH}$ 3.0 and 3.5, while above 6.0 the activity increased sharply reaching the maximum at $\mathrm{pH} 8.0$ and thereafter it decreased (Fig 1).

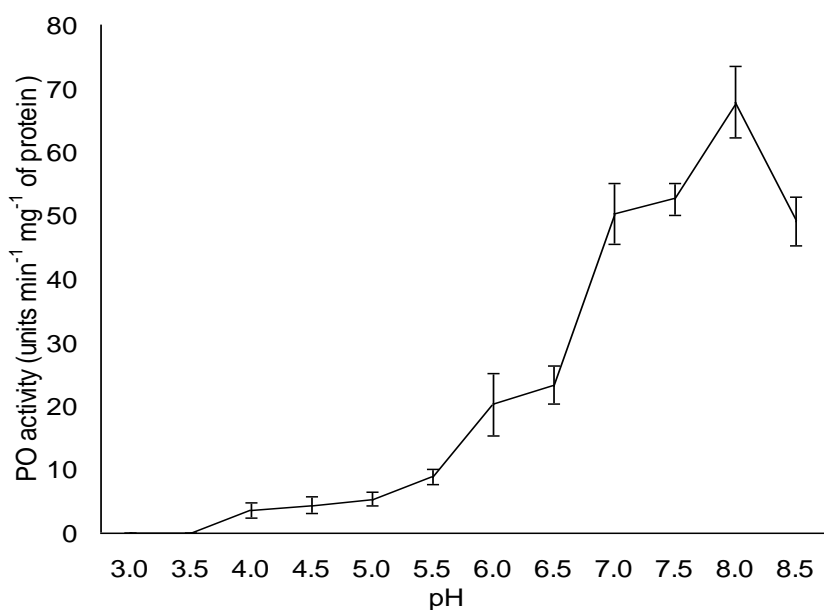

Fig. 1: Determination of optimum $\mathrm{pH}$ for $\mathrm{PO}$ activity. (mean $\pm \mathrm{SD} ; \mathrm{n}=8)$ ].

\subsection{Effect of exogenous elicitors}

The results showed that PO activity in S. tranquebarica was enhanced significantly by pre-treatment with various species of Gram negative and Gram positive bacteria (Fig 2).

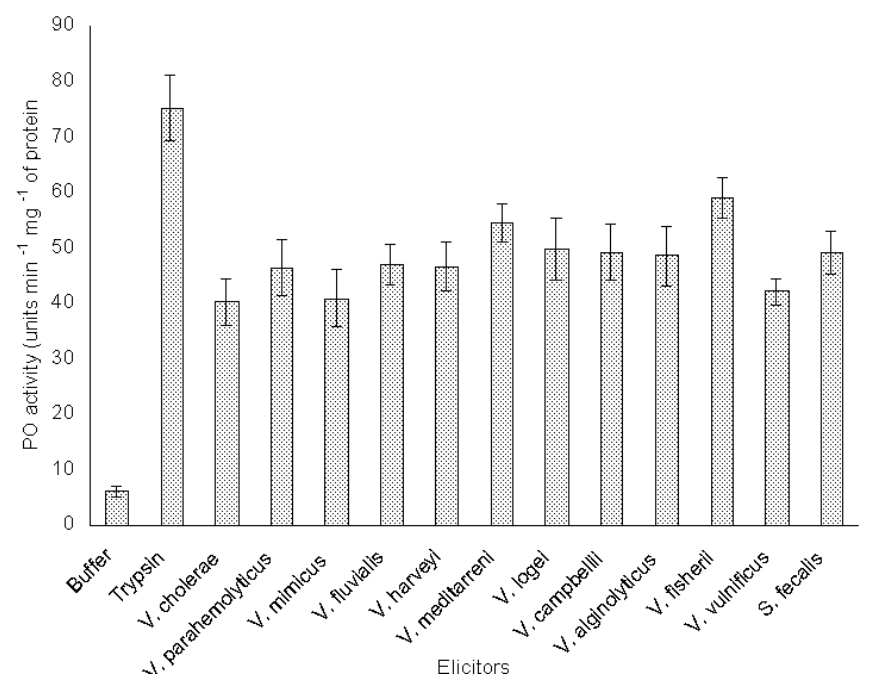

Fig. 2: Effect of exogenous elicitors on PO activity of haemocyte lysate from Scylla tranquebarica. (mean $\pm \mathrm{SD} ; \mathrm{n}=6)$ ].

Among the Vibrio spp, V. fisherii (58.94 \pm 3.63 units) and $V$. mediterenii $(54.50 \pm 3.22$ units) elicit the highest PO activity while, V. mimicus $(40.88 \pm 5.13$ units) and V. cholerae (40.24 \pm 4.21 units) express the least activity.

Meanwhile, the Gram positive bacteria, Streptococcus fecalis, elicit phenoloxidase activity of $49.00 \pm 3.90$ units. However, the stimulative effect of trypsin was found to be significantly $(P<0.05)$ higher than that by the different microbes used in the study. The presence of PO activity in buffer control could be due to formation of PO during preparation or handling.

\subsection{Effect of inhibitors on PO activity}

Significant $(P<0.05)$ reduction in PO activity of $S$. tranquebarica was observed in the presence of inhibitors. The average PO activity after addition of $10 \mathrm{mM}$ of thiourea, sodium azide and EDTA was found to be $30.91 \pm 1.97,48.37 \pm 7.00$ and 
$50.47 \pm 2.15$ units, respectively. Meanwhile, in control, the PO was found to be $73.59 \pm 6.35$ units in the absence of inhibitors. The result implies that these chemicals can partially prevent the expression of the enzyme.

\subsection{Effect of calcium and magnesium dependence of PO activity}

The expression of PO depends on the presence of $\mathrm{Ca}^{2+}$ or $\mathrm{Mg}^{2+}$ ions (Fig 3). A concentration of either $20 \mathrm{mM} \mathrm{CaCl}_{2}(46.27 \pm$ 3.32 units $)$ or $20(53.92 \pm 2.43$ units $)$ to $50 \mathrm{mM} \mathrm{MgCl}_{2}(54.50 \pm$ 2.71 units) added in vitro showed the highest PO activity. Decreased activity was observed in both below and above this level of divalent cations.

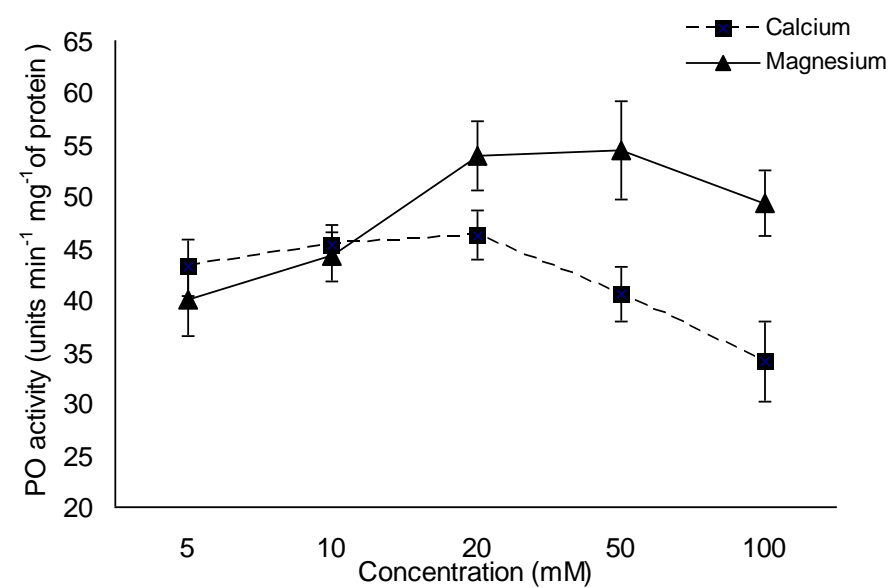

Fig. 3: Stimulative effect of calcium and magnesium ions on $P O$ activity in HLS of Scylla tranquebarica. (mean $\pm \mathrm{SD} ; \mathrm{n}=8)$ ].

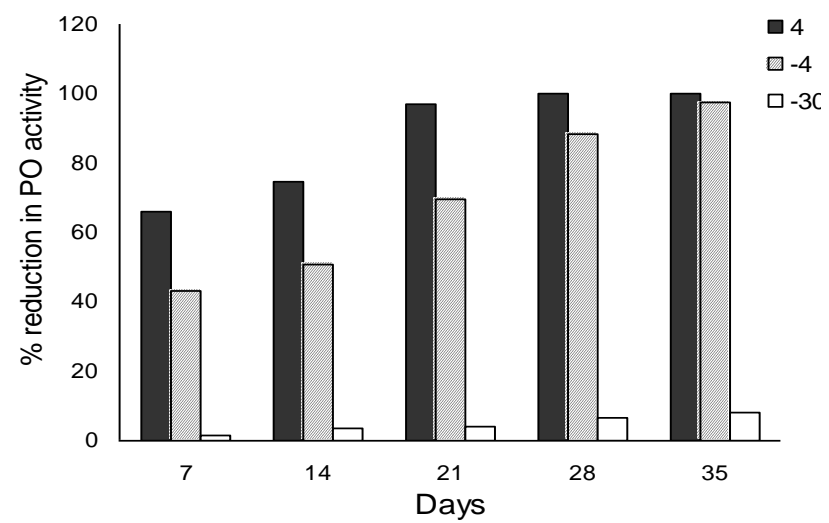

Fig. 4: Storage stability of proPO in HLS of crab, Scylla tranquebarica. $(\mathrm{n}=6)$.

\subsection{Storage stability}

The stability of enzyme at three different temperatures (4, -4 and $-30{ }^{\circ} \mathrm{C}$ ) was evaluated at weekly intervals for 5 weeks. The reduction in enzyme activity was calculated as percentage and is shown in Fig 4. The proPO became inactivated after 3 weeks of storage at $4{ }^{\circ} \mathrm{C}$, while it shows some activity even on $35^{\text {th }}$ day when stored at $-4{ }^{\circ} \mathrm{C}$. The activity of this enzyme in HLS could preserve for a long time (35 days) on storage at $-30{ }^{\circ} \mathrm{C}$. Thus it can be concluded from the study that proPO is sensitive to storage conditions.

\subsection{Gel filtration chromatography}

The elution profile of haemocyte lysate of $S$. tranquebarica by Sephadex G200 gel is shown in Fig 5. The protein profile of eluates revealed first two prominent peaks followed by several minor peaks. Fraction number 6 to 22 showed significant quantity of protein and PO activity while fraction no 23 to 76 has no PO activity but contain varying levels of low protein concentration. Based on the above observations, the fractions containing highest PO activity were pooled and concentrated for use in polyacrylamide gel electrophoresis (PAGE).

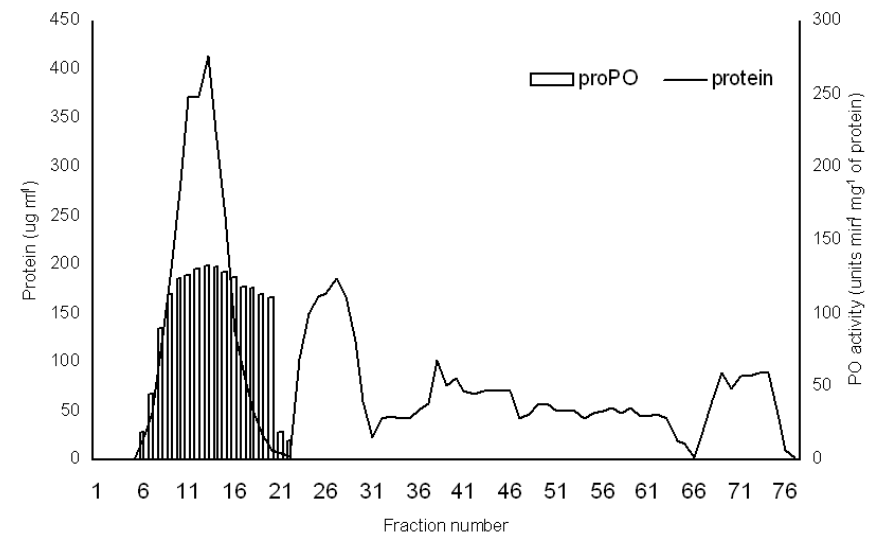

Fig. 5: Elution profile of haemocyte lysate by Sephadex G-200 column chromatography.
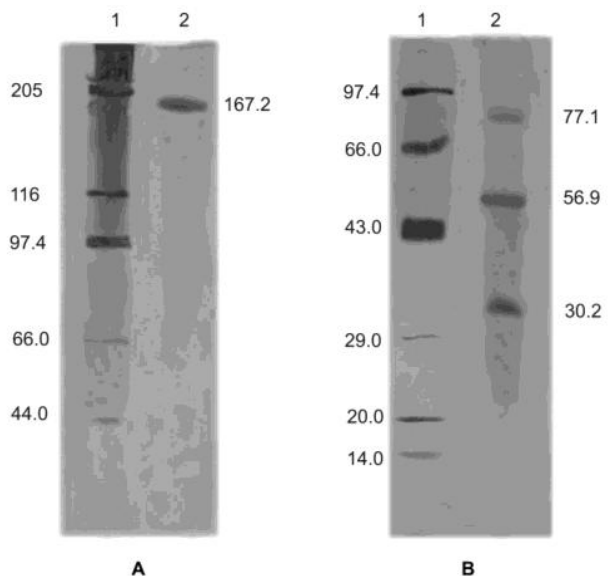

Fig. 6: Electrophoresis of the enzyme proPO from the haemocyte lysate of Scylla tranquebarica.

(A) Native PAGE of proPO purified by gel filtration chromatography. Lane 1, protein molecular weight markers; lane 2, proPO

(B) SDS-PAGE of proPO purified by gel filtration chromatography. Lane 1, protein molecular weight markers; lane 2, proPO.

To determine the molecular weight, the enzyme was subjected to native and SDS-PAGE. After running the native PAGE, the gel, treated with trypsin and L-dopa revealed a faint black patch and later it absorbs the coomassie blue stain and appears as a protein band. This protein is proPO and appears as a single prominent band having approximately 167.2 kDa (Fig 6A). At the same time, there was no observable dark patch or band after treating the SDS PAGE gel with trypsin and L-dopa. But after 
staining, three bands having molecular weights of approximately 77.1, 56.9 and $30.2 \mathrm{kDa}$ (Fig 6B) were visible.

\section{DISCUSSION}

Microbes and parasites can naturally enter into the arthropod through wounds or contamination of food. The response to this entry can often visible as dark spots in the cuticle of the arthropods. This colour is caused by melanin, which is produced as a product of the proPO system in arthropods. The enzyme responsible for the melanin formation is phenoloxidase (PO), which catalyses the oxidation of phenols to quinines that subsequently polymerize into melanin. During the formation of melanin, toxic metabolites are formed with reported antimicrobial properties [4].

It is well documented that in arthopods, the zymogenic form, proPO is converted to PO through a proteolytic cleavage by a serine protease such as trypsin [13] and this activity has been demonstrated in haemocyte lysate of decapod crustaceans [14]. Similarly, the present study confirms the location of PO as proPO in haemocytes of $S$. tranquebarica.

S. tranquebarica PO showed highest specificity for Ldopa as substrate. In general, the enzyme-catalysed reactions proceed via the formation of enzyme substrate complex in which substrates bounds non-covalently to the active site of the enzyme [15] and the use of L-dopa as substrate in detecting the PO activity was reported in many crustaceans. The $K \mathrm{~m}$ value for L-dopa in PO activity of this crab was found to be much close to the reports from Penaeus californiensis [7]. Moreover, PO of crustaceans has higher activity with diphenols and the result of the present study is comparable to the above reports from various invertebrates. The optimum $\mathrm{pH}$ for PO activity is 8.0 in S. tranquebarica, which was similar to brown shrimp, $P$. californiensis [7]. $\mathrm{pH}$ forms an important factor for the enzyme action because the ionization of aminoacid residues in the active site of an enzyme depends on the optimum $\mathrm{pH}[13]$.

In our study using bacteria as elicitors, both Gram positive and Gram negative microbes stimulate the inactive proenzyme and convert to active PO. The proPO system is known to be triggered by the cell wall components of bacteria namely lipopolysaccharides and peptidoglycan of gram negative and gram positive bacteria and recognition of these microbial polysaccharides result in the stimulation of a serine protease (prophenoloxidase activating enzyme: ppAE) that cleaves proPO at a specific peptide bond near its amino terminus, which activates this enzyme from haemocytes $[4,16]$. The highest level of PO activity was reached after incubating with trypsin and this could be due to the complete or near maximum active site formation for the substrate than that of the microbes. Meanwhile, sodium azide, thiourea and EDTA were able to inhibit the expression of PO of $S$. tranquebarica and this occurs when inhibitors combine specifically with the enzyme to reduce its ability to convert substrate into product [15]. In the present study, the optimum requirement of $\mathrm{Ca}^{2+}$ and $\mathrm{Mg}^{2+}$ were checked separately for PO activity and revealed that either of these cations helps in PO expression of $S$. tranquebarica. Generally, the arthropod proPO system required a threshold concentration of calcium for proPO activation [16] and the optimum levels of these two divalent cations, either separately or in combination of both has been reported in several decapods $[5,18]$. Furthermore, the ionic concentration in the hemolymph of decapods varies with environmental conditions, such as temperature and salinity [19]. Combining this fact and the result of the present study, the quality of the pond water is critical in maintaining the optimal levels of these divalent ions in order to stimulate the proPO system and strengthen the defence mechanism of $S$. tranquebarica. Higher concentrations of both ions invariably suppress the PO activity. The molecular mass of proPO in $S$. tranquebarica was found to be 167.2 KDa (Fig 6A). Several earlier reports suggest a wide range of molecular mass for proPO in arthropods. It exists as a monomeric protein weighing $113.9 \mathrm{kDa}$ in P. californiensis [7], a tetramer having $300 \mathrm{kDa}$ in crayfish [20], $37 \mathrm{kDa}$ in Procambarus clarkii [21] and $69.5 \mathrm{kDa}$ in Charybdis japonica [22].

\section{CONCLUSION}

In conclusion, phenoloxidase exists as a proenzyme (proPO) in the haemocytes of $S$. tranquebarica. The enzyme shows the substrate specificity to L-dopa with optimum activity at $\mathrm{pH}$ 8.0. The activation responses towards polysaccharides containing microbes and inhibitory properties towards different chemicals in vitro resemble the proPO activation system of many related decapod crustaceans and also requires divalent cations like $\mathrm{Ca}^{2+}$ or $\mathrm{Mg}^{2+}$ in significant concentrations for its activity. The proenzyme can store at $-30{ }^{\circ} \mathrm{C}$ without losing its activity for a minimum period of 35 days. The proPO has a molecular mass of approximately 167.2 $\mathrm{kDa}$ on native PAGE, which was resolved into three bands with molecular mass of approximately 77.1, 56.9 and $30.2 \mathrm{kDa}$. Future studies like sequencing and molecular cloning can reveal the critical functional roles of this enzyme cascade in $S$. tranquebarica.

\section{REFERENCES}

1. Bachere E. Shrimp immunity and disease control. Aquaculture. 2000; 191: 3-11.

2. Destoumieux D, Muñoz M, Cosseau C, Rodriguez J, Bulet P, Comps M, Bachere E. Penaeidins, antimicrobial peptides with chitin-binding activity, are produced and stored in shrimp granulocytes and released after microbial challenge. Journal of cell science. 2000; 113: 461-469.

3. Sritunyalucksana K, Söderhäll K. The proPO and clotting system in crustaceans. Aquaculture. 2000; 191: 53-69.

4. Söderhäll K, Cerenius L. Role of the prophenoloxidase-activating system in invertebrate immunity. Current Opininon Immunology. 1998; 10: 23-28.

5. Sung HH, Chang HJ, Her CH, Chang JC, Song YL. Phenoloxidase activity of hemocytes derived from Penaeus monodon and Macrobrachium rosenbergii. Journal of Invertebrate Pathology. 1998; 71: 26-33.

6. Houton C, Williams JA, Hawkins LE. The effects of a live in vivo pathogenic infection on aspects of the immunocompetence of the common shore crab, Carcinus maenas (L.). Journal of Experimental Marine Biology and Ecology. 1997; 211: 115-128. 
7. Gollas-Galván T, Hernández-López J, Vargas-Albores F. Prophenoloxidase from brown shrimp (Penaeus californiensis) hemocytes. Comparative Biochemistry and Physiology. 1999; 122B: 77-82.

8. Mangkalanan S, Sanguanrat $\mathrm{P}$, Utairangsri $\mathrm{T}$, Sritunyalucksana $\mathrm{K}$, Krittanai C. Characterization of the circulating hemocytes in mud crab (Scylla olivacea) revealed phenoloxidase activity. Devlopmental and Comparative Immunology. 2014; 44: 116-123.

9. Söderhäll K, Smith VJ. Separation of the hemocyte population of Carcinus maenas and other marine decapods and prophenoloxidase distribution. Developmental and Comparative Immunology. 1983; 7: 229-239.

10. Alsina M, Blanch AR. Improvement and uptake of a set of keys for the biochemical identificatyion of Vibrio species. Journal of Applied Bacteriology. 1994; 77: 719-721.

11. Laemmli U.K. 1970. Cleavage of structural proteins during assembly of the head of bacteriophage $\mathrm{T}_{4}$. Nature 227: 680-685.

12. Lowry OH. Rosebrough NL, Farr AL, Randall RJ. Protein measurement with Folin phenol reagent. Journal of Biological Chemistry. 1951; 193: 265-275.

13. Söderhäll K, Cerenius L. Role of the prophenoloxidase-activating system in invertebrate immunity. Current Opinion Immunology. 1998; 10: $23-28$.

14. Söderhäll K, Cerenius L. Crustacean immunity. Annual Review of Fish Diseases. 1998; 2: 3-23.

15. Wilson K. Protein and enzyme techniques. In: Wlison K, Walker J, editors. Practical Biochemistry. Principles and Techniques, Cambridge University Press; Cambridge; 1995, p. 162-226.

16. Liu H1, Jiravanichpaisal P, Cerenius L, Lee BL, Söderhäll I, Söderhäll $\mathrm{K}$. Phenoloxidase is an important component of the defense against Aeromonas hydrophila Infection in a crustacean, Pacifastacus leniusculus. Journal of Biological Chemistry. 2007; 282: 33593-33598.
17. Leonard C, Ratcliffe NA, Rowley AF. The role of prophenoloxidase activation in non-self recognition and phagocytosis by insect blood cells. Journal of Insect Physiology. 1985; 31: 789-799.

18. Hernández-López J, Gollas-Galván T, Vargas-Albores F. Activation of the prophenoloxidase system of the brown shrimp (Penaeus californiensis Holmes). Comparative Biochemistry and Physiology. 1996; 113C: 61-66.

19. Sartoris FJ, Põrtner HO. Increased concentrations of haemolymph $\mathrm{Mg}^{2+}$ protect intracellular $\mathrm{pH}$ and ATP levels during temperature stress and anoxia in the common shrimp Crangon crangon. Journal of Experimental Biology. 1997; 200: 785-792.

20. Aspán A, Söderhäll K. Purification of prophenoloxidase from crayfish blood cells, and its activation by an endogenous serine proteinase. Insect Biochemistry. 1991; 21: 363-373.

21. Lanz H, Hernández S, Garrido-Guerrero E, Tsutsumi V, Aréchiga H. Prophenoloxidase system activation in the crayfish Procambarus clarkii. Developmental and Comparative Immunology. 1993; 17: 399 406.

22. Liu G, Yang L, Fan T, Cong R, Tang Z, Sun W, Meng X, Zhu L. Purification and characterization of phenoloxidase from crab Charybdis japonica. Fish and Shellfish Immunology. 2006; 20: 47-57.

\section{How to cite this article:}

Sabu AS, Jithendran KP, Gopal C. Properties of phenoloxidase from haemocytes of Scylla tranquebarica. J App Biol Biotech. 2016; 4 (01): 047-052. DOI: 10.7324/JABB.2016.40109 